Настасија 3. Перић*

Универзитет у Београду ${ }^{1}$

Филолошки факултет
2-526.65(497.6 Mala Gostilja)"13““

94:003.349

https://doi.org/10.18485/zivjez.2021.41.1.5

Оригинални научни рад

Примљен 30/08/2021

Прихваћен 25/12/2021

\title{
НАДГРОБНИ НАТПИС НА СТЕЪКУ У СЕЛУ МАЛА ГОСТИЉА
}

Надгробни натпис на стећку у селу Мала Гостиља забележен је у књизи Стећии, каталошко-топографски преглед Шефика Бешлагића, али није подвргнут детаљној графијској анализи, нити публикован са пратећом фотографском документацијом. Анализом слова и правописних одлика натписа покушаћемо да откријемо његове палеографске особености, које могу дати допринос увиду у развој ћирилице и епиграфског писма. Покушаћемо га локализовати просторно и временски, стављајући га тако у одговарајући историјски миље. У недостатку археолошких и других истраживања, покушај датирања овог надгробника свешће се на компаративни метод, односно закључивање уз помоћ аналогија са већ датираним и анализираним натписима, као и на осветљавање културно-историјског контекста везаног за средњовековну Босну и околину Вишеграда.

Кључне речи: стећак, ћирилица, натпис, Босна, Твртко Котроманић, средњи век, XIV век.

\section{О стећцима}

Када расправљамо о стећцима, сусрећемо се са недоследним коришћењем самог назива у стручној литератури. Шефик Бешлагић под стећцима подразумева камене надгробне споменике карактеристичне за подручје старе босанске државе, те тако обједињује једним именом средњовековне споменике, док су се у претходној литератури стећцима називали само сандуци и слемењаци, или аморфни споменици када се налазе на истој некрополи као и слемењаци/сандуци. Крстаче и стубови се у стећке нису убрајали, како

\footnotetext{
* Универзитет у Београду, Филолошки факултет, Студентски трг 3, 11000 Београд; gorskimis12@gmail.com

1 Стипендиста Министарства науке, просвете и технолошког развоја, ангажован у научноистраживачкој установи Филолошки факултет у Београду
} 
због свог другачијег облика, тако и због временске разлике која дели крстаче/стубове од слемењака сандука.

Стећци у ужем смислу јесу монументални, камени надгробни споменици у облику сандука и слемењака, који временски припадају периоду позног српског средњег века. Иако се спорадично могу пронаћи стећци чије се порекло везује за XII век, већина њих датира се у XIV и XV век, а спорадично и у XVI век, када постепено престају да их користе као надгробнике. Њихова заоставштина наставља се у виду усправних споменика и крстача, које ипак, не припадају „класичном добу” културе стећака, те их заједно са стећцима у облику сандука, и сандука са кровом на слеме, називамо стећцима у ширем смислу. На њих ћемо мислити када користимо термин стећак у даљем раду.

Евидентирано их је укупно седамдесет хиљада, а натписи се срећу на око триста примерака, који су драгоцени за лингвистичке, археолошке и историјске анализе. Уписани су на листу УНЕСКО-ве светске баштине 15. јула 2016. године. На листи се нашло тридесет некропола, са четири хиљаде споменика на територији четири државе: Хрватске, Босне и Херцеговине, Србије и Црне Горе. Границе области простирања стећака јесу на северу река Сава, Јадранско море на југу, Лика на западу, док је источна граница везана за запад и југозапад Србије, и долину Ибра, Лима и Дрине. Сам назив „стећак” потекао је из XIX века, а називи у народу за некрополу стећака јесу: грчко, маџарско, турско, каурско, дивско гробље и мраморје. На самим стећцима, користио се назив кам, белег, зламен. Постоји пет главних врста стећака: плоча, сандук, слемењак, крстача и стуб, при чему последња два припадају завршном периоду културе стећака - XVI веку. Настали су под утицајем праисторијске, античке и раносредњовековне традиције, а од европске средњовековне традиције разликују се по својој бројности, монументалности и конфесионалној припадности. Натписи и орнаменти нису ретки, и могу бити сакралног и секуларног значења. ${ }^{2}$

\section{Стећак са натписом у селу Мала Гостиља}

\section{Орнаменти}

Шефик Бешлагић у својој књизи Стећии, Каталошко топографски преглед, даје попис стећака на простору Босне и Херцеговине, Хрватске, Србије и Црне

2 Подаци преузети са званичног сајта Министарства цивилних послова, сектора за науку и културу https://www.stecciwh.org/ u rubrici documents, Stecci Nomination File - 1504 
Горе. У њој је описана и некропола стећака у селу Мала Гостиља у општини Вишеград, удаљена од града Вишеграда 9 километара северно ваздушном линијом: „На локалитету Трутово брдо, на гребенастом терену сјеверозападне стране села, покрај пута, налази се некропола са 43 стећка (22 сандука, 1 комбиновани сљемењак-сандук и 20 сљемењака)" (Бешлагић 1971: 258). Бешлагић додаје да се пружају у правцу исток-запад, осим три који се пружају у правцу север-југ. Он, такође, наводи да је украшено шест стећака (2 сандука, 1 слемењак-сандук и 3 слемењака), а од орнамената у пластици наводи следеће: ,jабука, полумјесец, розета, круг, врпца од косих паралелица, мач, рука с мачем, рука с копљем, лук, стилизована биљка, двострука спирала са гроздовима и врло риједак мотив розете са завинутим листићима" (Бешлагић 1971: 258). У истом параграфу каже да на једном слемењаку постоји натпис „који саопштава да ту леже Вукић, син Вукашина Носаковича, и његова мајка Ружа”.

Нема сумње да је у питању исти локалитет, али су нам, због непрегледности терена, били доступни само наредних шест стећака - слемењака, груписаних међу храстовим дрвећем. До њих се долази сеоским путем, а стотинак метара се мора прећи пешке, шумском стазом, будући да се налазе на простору данашњег ловишта. Од ових шест, четири имају орнаменте: мотиве оружја у пластици - руку са копљем, лук и стрелу и мач, као и астрални мотив полумесеца, биљни мотив крина и спиралу. Један (који има у пластици урађен мач и лук са стрелом) има на себи и натпис (Слика 1.1a; линије слова су подебљане на Слици 1.16; приказ натписа на стећку и његов превод налазе се у Табели 1).

Табела 1. Приказ натписа на стећку и превод на српски језик

\begin{tabular}{|l|l|}
\hline Натпис на српскословенском & Превод на српски \\
\hline+ а єє мєжн в8кнғь сннь в8кашннь носако & Овде лежи Вукић син Вукашин носако \\
свощмь манкомь р8жомь & својом мајком Ружом \\
\hline
\end{tabular}

Натписно поље је правоугаоно, на бочној страни стећка, а натпис је писан уставом, премда се на њему увиђају одлике брзописа. Величина слова је приближно десет центиметара. На натпису нема бројева, лигатура, надредних знакова и знакова интерпункције. Десна ивица натписног поља овог надгробника је одваљена, те се може претпоставити да неколико слова недостаје.

3 [...нерашчитано]

4 [...нерашчитано] 


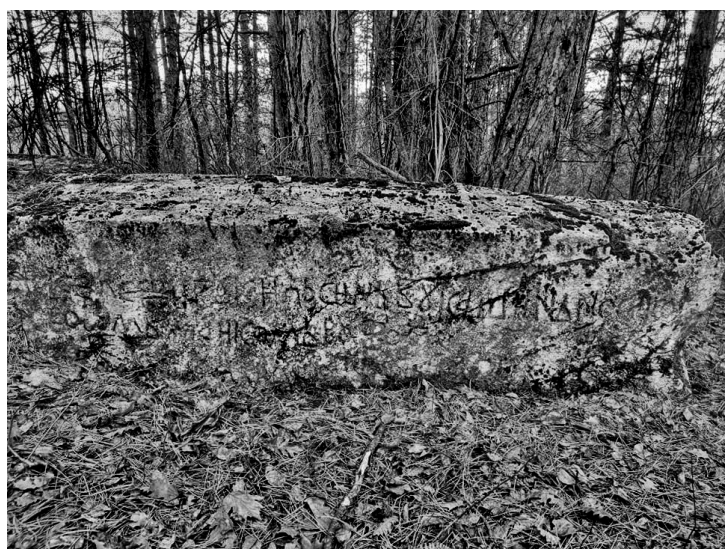

Слика 1.1a.

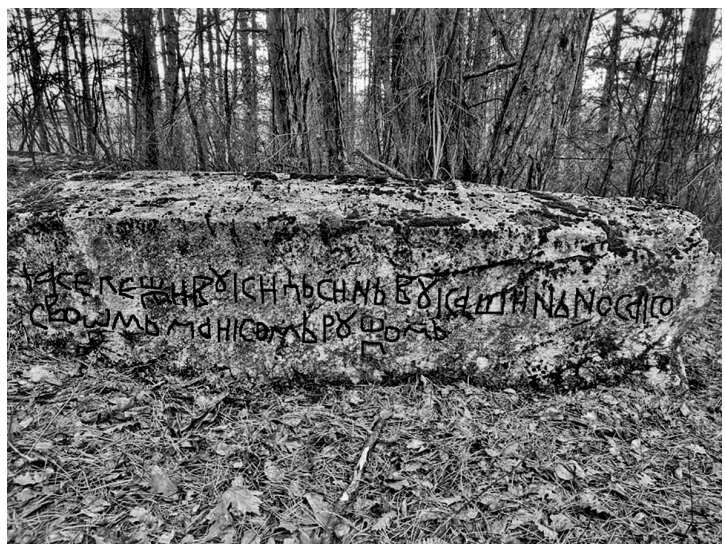

Слика 1.1б.

На „крову” стећка, с једне стране налази се мач, а с друге лук и стрела (Слика 1.2). У Лексикону српског средњег века, под одредницом „оружје” видимо да мачеви, који су коришћени у српском средњем веку, јесу били тешки, дворучни мачеви. Мач се користио још од бронзаног доба, али су у средњем веку постали јачи и дужи због оклопа и коњице. У XV веку, током Деспотовине, и даље се у наоружању користио мач због утицаја традиције, премда се још са доласком Турака сабља показала као ефикаснија, и почела се масовније уводити у наоружање српске војске још почетком XIV века. 
Лук је са копљем чинио основно бојно оружје, и њихове представе су врло честе у пластичној уметности стећака. Посебна новина коју је турска војска увела код Срба био је полукружни лук, који такође проналази своје место на многим надгробним споменицима.

Полагање прилога уз покојниково тело, био је незаобилазни обред који је пратио обичај сахрањивања. Прилози су се, у зависности од времена и народа, мењали, али су најчешће били везани за обезбеђивање покојниковог загробног живота; и састојали су се од новчића, керамике, фигурица и реликвија везаних за покојников духовни или световни идентитет. Стога је сахрањивање војника са оружјем увелико познато средњовековној пракси и почива на већ утемељеним праисторијским веровањима. Опште је познат готички дворучни мач, нађен испод једног стећка у околини Мостара (Бешлагић 1971: 225). У српској епици увиђамо остатке таквог веровања. У песми Смрт Марка Краљевића, Марко слутећи своју смрт одсеца главу свом коњу и уништава сабљу и копље. Коњ, сабља и копље чине јунакове епске атрибуте и непобитни су делови његовог идентитета, те стога не могу допасти шака ником другом. Међутим, када је престало сахрањивање са прилозима, мачеви се осликавају на надгробницима, уместо да се спуштају у гроб. Представљају симбол ратника или племства. Тако мачеви, али и други симболи, проналазе своје место у уметности стећака, иако им је првобитна функција била да покојнику припишу некакво његово својство: пол, занимање, верску припадност. Иако се о пластичним мотивима оружја на стећцима може говорити са становишта историје уметности, они не могу бити аргумент за датирање, управо због тога што је уметност стећака индивидуална и зависна од неколико фактора: вештине клесара, тврдоће камена, али и неговања старине од стране наручиоца или пак самог клесара. Стога, мотиви на стећцима не могу бити поуздани извори за датирање. Полукружни лук може указивати на усвајање турског модела израде оружја, односно на период након друге половине петнаестог века; али такође ова рудиментарна представа лука може се наћи на стећку уместо извијеног старијег лука са две кривине пошто је лакша за израду. Аналогија важи и за обратну ситуацију. Када се лук на две кривине пронађе на стећку не можемо га нужно, само на основу те особине сместити у период пре Турских освајања, јер израда таквог лука може бити и последица стилизације, као и последица неговања традиције и традиционалног српског лука. Једино што се поуздано може рећи, на основу ових мотива у пластици, јесте да је покојник испод овога стећка највероватније био ратник, или можда припадник племства. 


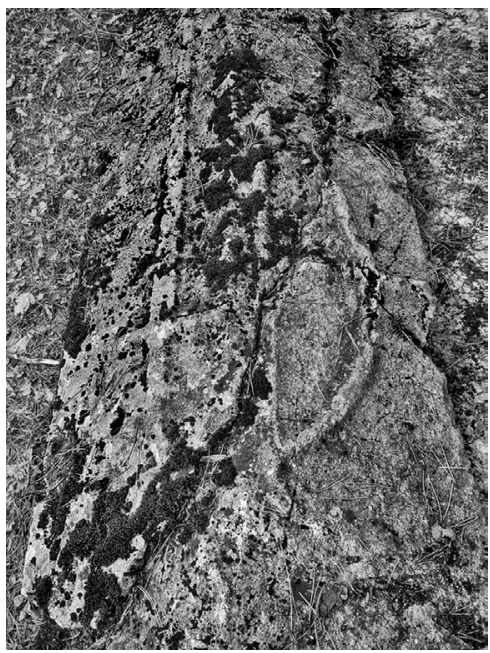

Слика 1.2.

Још једно оружје српске војске јесте копље. Сама реч је прасловенског порекла. Било је дужине до два метра. Рука са копљем у пластици налази се на другом стећку (Слика 2.1). На другој страни истог стећка приказан је кратак мач (Слика 2.2). На краћим странама стећка налазе се орнаменти у пластици у облику спирале (Слика 2.3). На овом другом стећку не постоји натпис, али симболика оружја јасно говори о занимању покојника. И он је несумњиво био ратник, што показују мотиви руке са копљем и мачем на двема паралелним странама стећка.

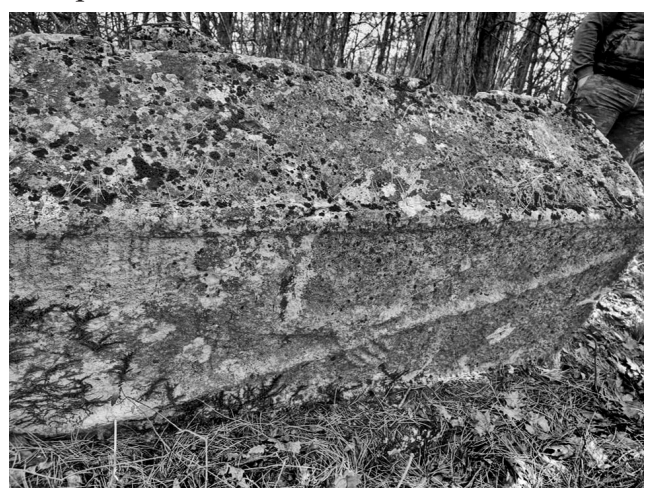

Слика 2.1. 


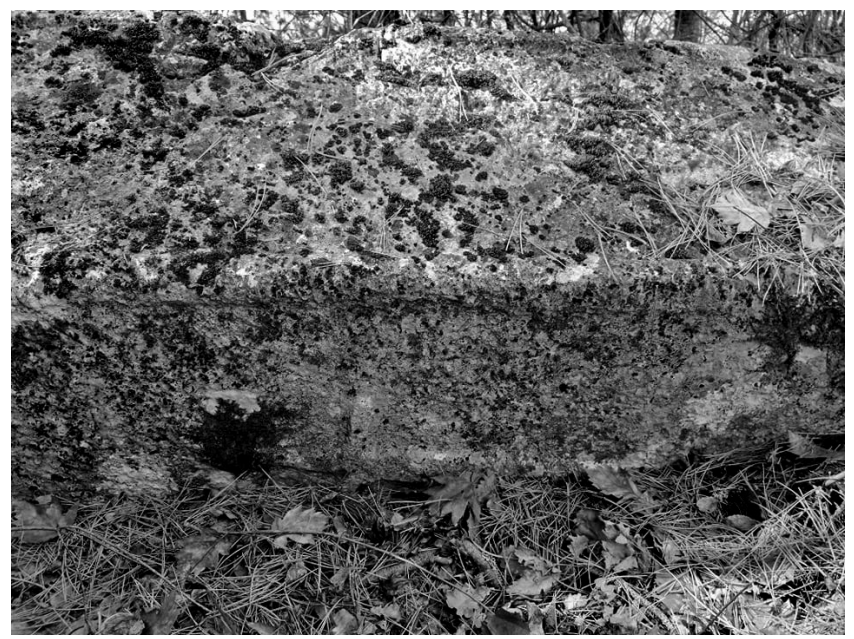

\section{Слика 2.2.}

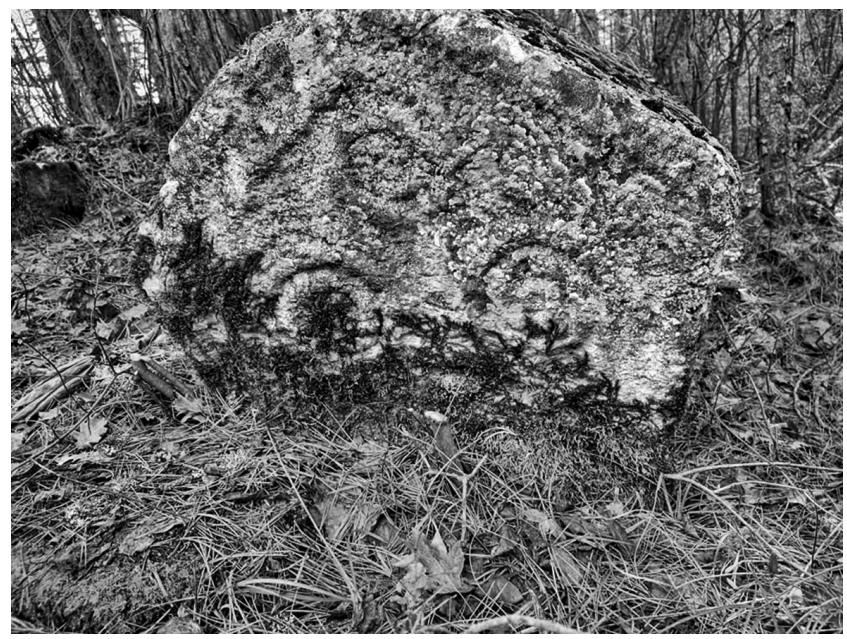

\section{Слика 2.3.}

На једном од слемењака налази се и астрални мотив полумесеца (Слика 3.1). 


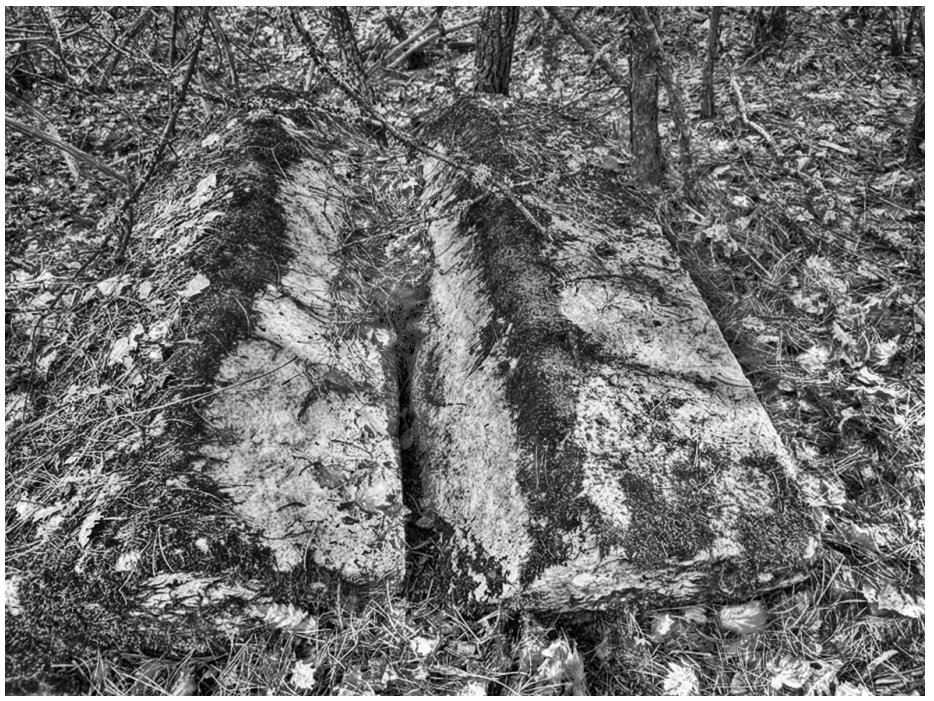

Слика 3.1

\section{Историјске околности}

Да бисмо исцрпли све податке који могу пружити увид у настанак овог стећка, неопходно је да се позабавимо историјским контекстом везаним за околину Вишеграда у средњем веку (в. Срејовић и др. 2000; Ћирковић 1997; Ћирковић и др. 1999). Ако желимо да дамо приказ контекста историјских збивања у средњовековној Босни, немогуће је заобићи босанског бана, касније и краља, Твртка Котроманића, чијим су заслугама Босни припале прекодринске територије, у годинама након Маричке битке.

Петнаестогодишњи Твртко Котроманић, праунук Драгутина Немањића, дошао је на чело босанске државе након краткотрајне владавине свог оца, кнеза Владислава, који је наследио брата, босанског бана Стефана другог Котроманића 1353. године. Малолетни наследник је са својом мајком, удовицом кнеза Владислава, морао да се избори са нередима у држави, које је највероватније изазивала властела. У чему су се огледали босански нереди није познато, али се поуздано зна да је постојало незадовољство, чим се једном делу властеле морало повлађивати повластицама, што можемо видети на примеру повеље кнезу Влатку Вуковићу. Његову владавину обележила је освајачка политика у Далмацији, али обележили су га и ратни походи и раз- 
мирице са краљем Лајошем, који су се завршили Твртковим ослобађањем Босне од вазалног односа. У то време је у Босни започет и грађански рат, а са друге зараћене стране стајао је његов рођени брат, коме се касније придружио и хумски господар Санко Милтеновић, потпомогнут српским обласним господаром Николом Алтомановићем, који је постао моћан коначним протеривањем стрине Гојиславе Војиновић и наслеђивањем области свог стрица. Међутим, Никола Алтомановић, у годинама које претходе Косовској бици, избачен је из борбе за престо српске државе. Кнез Лазар га је заробио уз помоћ Лајоша и Твртка. Његове области су одузете, а Котроманићи, Балшићи и Хребељановићи поделили су их између себе.

Западни део Алтомановићевих области (Подриње и предели око Пријепоља) припао је Твртку. Областима које је добио бан, а касније и краљ Твртко, припада и територија данашње општине Вишеград, односно село Мала Гостиља, у којем се налазе поменути стећци. До смрти босанског краља Твртка ове области остају део његове територије, а након њега припадају краљу Дабиши. Најпосле, након Дабишине смрти, припале су његовој жени Јелени. Јелена Груба владала је од 1395. године, и током њене владавине долази до јачања властеле, те под директном влашћу краља, односно краљице остаје само централна Босна, док се њени остали делови расподељују међу обласним господарима. Почетком петнаестог века највећи део Босне држао је Хрвоје Вукчић (западну Босну, Далмацију, а до краја живота проширује своју владавину и на хрватске територије). Павле Раденовић је владао облашћу око Вишеграда и Требиња, док је Сандаљ Косача држао у свом поседу леву страну Лима, до ушћа у Дрину. За Раденовића и његове синове (Петра и Радослава Павловића, и унука, војводу Иваниша, Радослављевог сина) везује се планина Бујак, где су имали свој двор, и њихова некропола у засеоку Раонићи, Каоштице. Након краљице Јелене било је још босанских краљева, али Вишеград је у сваком случају „од конца друге половине XIV века припадао породици Павловића као и Устиколина, Међеда и Добрун” (Вего 1957: 123). Земља Павловића добиће назив вилајет Павли, након пада Босне 1463. године.

Захваљујући овим подацима, ову некрополу вероватно можемо везати за оснивање Босанске краљевине, односно најраније за крај XIV и почетак XV века. Стећци у околини Вишеграда настали су под несумњивим утицајем босанске државе, а да је у питању њен утицај потврђује и појава стећака у западној Србији - Растиште, Мраморје, у областима које су припадале босанском бану, а касније и босанском краљу Твртку. Дакле, култура стећака, 
која је свакако настала пре XIV века у данашњој централној Босни, проширила је свој утицај и на новоосвојене области, на простор данашње Хрватске, Црне Горе и Србије.

\section{Графијска анализа}

Епиграфски споменици, заједно са осталом палеографском и рукописном грађом, помажу стварању целокупне слике развоја ћирилице. Захваљујући датираним и морфолошки, графијски и ортографски анализираним споменицима, могуће је одредити време настанка недатираних и неевидентираних споменика, премда треба имати у виду да овакав метод датирања не може сваки пут дати довољно прецизне резултате.

Датирање се може извршити помоћу облика слова, који пак може варирати у зависности од материјала на којем је уклесан натпис, вештине писара и утицаја књишке, рукописне грађе. Нека слова су посебно релевантна за хронолошку анализу, јер су се мењала кроз време. Динамични елементи слова су најчешће попречне црте, односно хоризонталне пречкице, које су старије у односу на млађе, косе пречкице, настале под утицајем брзописа. Кључна црта на основу које ћемо споменичну грађу поделити на ону пре и после краја XIII века јесу одлике брзописа, које из рукописних записа прелазе и на епиграфске натписе. Упоређивање овог натписа са другим ћириличним натписима извршићемо на основу расположивих извора.

Од слова на овом стећку прокоментарисаћемо само она која су значајна за анализу овог стећка. Најпре, ако желимо да говоримо о особинама брзописа на овом надгробном натпису, морамо узети у обзир писање слова која поседују минускулне особине, односно слова чији крајеви премашују дволинијски систем (A, k, z, р, џ, ц, or). Од ових слова, на стећку се налазе „p” и лигатура 8, која јесу минускулне природе, али су на овом стећку записана у оквиру дволинијског система, осим првог 8, које је измештено ка горе. Развој ка минускули почиње са мењањем изгледа слова „а”, које продужава стабло изнад и испод стомака. Минускулно „в” подсећа на квадрат, а минускулно „К” на полумесец. Слово „м” постаје минускулно тако што се доња средишња црта спушта испод линије, док се код слова „ж” бочни краци продужавају (понекад чак и средишњи крак).

Опис слова са стећка значајних за датирање:

А - Овде се јавља омчасто „а”, са продуженим хоризонталним стаблом и облим стомаком. Оно је старије од млађег, рачвастог „а”. Захваљујући 
продуженом стаблу, као и стаблу које је на примеру једне графеме искошено удесно, можемо видети утицај минускуле.

В -Састоји се од усправне црте и петљица које се спајају на њеној средини, или се не спајају међусобно, већ са хоризонталном цртом. Овде су заступљена оба типа овог слова. Петљица може бити полукружна, троугласта, елипсаста, квадратна. Овде је троугласта, са благим заобљавањем углова.

Е -У натписима јавља се и у угластом и у старијем, српастом облику; а када је српасто у корелацији је са словом „с”. Овде је српасто.

Ж - Ово слово се не јавља у многим натписима. Најстарији тип је састављен од две косе црте које се пресецају на средини треће, усправне, и има изглед астериска. Други тип садржи полукружне косе краке. Овде срећемо другачије слово, чију уздужну линију не пресецају коси, већ угласти краци.

И - На овом споменику налази се у облику грчке „ите”,односно има водоравну црту. То је старији облик.

t - На стећку је ово слово угластог типа. Такав облик се први пут јавља у Мирослављевом јеванђељу. Карактеристично је за споменике босанско-херцеговачког подручја (који негују глагољску традицију).

К - Лева црта је вертикална, а десна извијена, српаста и не спаја се са водоравном. Овакво слово је минускулно.

8 - Диграф је старији облик, а лигатура млађи. Овде се јавља само лигатура.

b - „Јер” се јавља у више облика. Најкарактеристичнији је облик са усправном цртом благом повијеном удесно, јер представља одлику брзописа.

Као што из изгледа слова можемо закључити, о присуству минускуле у словима „а" и ,јер” може се дискутовати, али је само „к” поуздано минускулно. Захваљујући слову „к” можемо закључити да овај натпис не може бити старији од XIII века. Томе иде у прилог и карактеристично угласто ђерв, које означава глас „ћ”, и које у том значењу улази у епиграфију тек након XIII века. У Табели 2 је дат приказ слова. 
Табела 2. Приказ слова са натписа на стећку у Малој Гостиљи

\begin{tabular}{|c|c|c|}
\hline a & $\mathrm{H}$ & $\mathrm{b}$ \\
\hline Б & 0 & ь $\boldsymbol{\Delta}$ \\
\hline В & $\Pi$ & bI \\
\hline$\Gamma$ & $\rho$ & Ł \\
\hline A & $c$ & Id \\
\hline$\epsilon$ & $T$ & IE \\
\hline ж & $\alpha, \gamma$ & 10 \\
\hline$z$ & $\phi$ & A, $\mathrm{AA}$ \\
\hline$\ddot{i}$ & $x$ & X, $1 \mathrm{~K}$ \\
\hline $\mathrm{H}$ & $\omega$ & $\theta$ \\
\hline$\hbar$ & $\Psi$ & 兰 \\
\hline I & 世 & $\checkmark$ \\
\hline-1 & 4 & $\mathrm{Y}$ \\
\hline
\end{tabular}

\section{Opmozpaфuja}

Анализа овог натписа вршиће се по угледу на образац морфолошке анализе из књиге Најстарији српски ћирилски натписи (2008) Бранкице Чигоје, као и делом Петра Ђорђића Историја српске ћирилище. 
На овом стећку посебно је карактеристична реч „свошмь”, у којој „омега” служи да забележи гласовну групу ,јо”. У књизи Ћирилични натписи централног Балкана Горана Комара (2018) налазимо још један натпис, у којем можемо видети „омегу” која означава гласовну групу „јо”: „своши”. У питању је натпис у селу Лепеница (Ковањ) код Рогатице (Комар 2018: 789). Исту ситуацију затичемо и на натпису на гробној плочи Радосава Хераковића (Комар 2018: 215). На натпису Рађа Галчића у Величанима наћи ћемо облик „свођши”(Комар 2018: 114). Међутим, ову заменицу најчешће ћемо пронаћи у облику „свои”, као на пример на натпису Херака на плочи под крстом у селу Дерани код Бољуна (Комар 2018: 235), на стећцима слемењацима у селу Љути (Комар 2018: 327), у селу Пипери (Комар 2018: 815). Некад можемо затећи и облике: „своеи” (Комар 2018: 812), али и „своишомь” (Комар 2018: 800). Можемо закључити да постоји недоследност у писању ове заменице, као и да се „омега” некад користи за писање гласа „о” али и гласовне групе „јо”. Такође, на овом стећку запажамо постојање двају „о [о/ю]”, од којих је једно искоришћено за ознаку групе ,јо” у „своюмь”, а друго за означавање исте групе и истог наставка у речи „маикомь”.

\section{Закључак}

Датирање споменичне грађе уз помоћ графијске, ортографске и историјске анализе не може увек донети прецизне резултате. Историја уметности, иако може расправљати о ликовним представама на стећцима, не може нам пружити информације о самој старини стећака. Уметност културе стећака зависна је од великог броја фактора, па је јасно зашто нам орнаменти још увек нису пружили корисне информације везане за хронолошку анализу. За разлику од историје уметности, графија је у овом случају пружила прецизније закључке. Због присуства минускулног облика слова „к” и слова „ђерв”, овај стећак не можемо сместити у период пре краја XIII века. У овом случају историја нам је пружила највећи спектар података. Захваљујући познавању Тврткових освајања, овај стећак не можемо сместити у време које претходи Маричкој бици, односно крају XIV века. Стога некрополу у селу Мала Гостиља можемо, са извесном сигурношћу, сместити најраније у крај XIV века. 


\section{ЛИТЕРАТУРА}

Бешлагић 1982: Ш. Бешлагић, Стећйи - култура и уметност. Сарајево:

Веселин Маслеша.

Бешлагић 1971: Ш. Бешлагић, Стећици, каталошко-топографски преглед.

Сарајево: Веселин Маслеша.

Вего 1957: М. Вего, Насеља босанске средњовековне државе. Сарајево:

Свјетлост.

Ђорђић 1990: П. Ђорђић, Историја српске ћирилище: палеографско-филолошки прилози. Београд: Завод за уџбенике и наставна средства.

Комар 2018: Г. Комар, Ћирилични натписи на стећчима. Београд: Штампар Макарије, Вечерње новости.

Срејовић и др. 2000: Д. Срејовић и сарадници, Историја српског народа.

Београд: Српска књижевна задруга.

Ћирковић 1997: С. Ћирковић, Срби у средњем веку. Београд: Идеа.

Ћирковић и др. 1999: С. Ћирковић, Лексикон српског средњег века. Београд: Knowledge.

Чигоја 2008: Б. Чигоја, Најстарији српски ћирилски натписи. Београд:

Чигоја. 
Nastasija Z. Perić

\section{TOMBSTONE INSCRIPTIONS IN THE VILLAGE NAMED MALA GOSTILJA}

\section{Summary}

This paper deals with the analysis of the inscription on the tombstone (stećak) in the village Mala Gostilja, near Višegrad. Appearance of certain letters, their shapes, and form can help us date this tombstone. Thanks to historical context, this tombstone can be chronologically situated at the end of 14th century and the beginning of the 15 th century.

Keywords: stećak, Cyrillic script, inscription, Bosnia, Tvrtko Kotromanić, Middle Ages, XIV century. 